\title{
LARVAE OF ALAUS MYOPS, A. OCULATUS, CHALCOLEPIDIUS PORCATUS, HEMIRHIPUS APICALIS AND GENERIC LARVAL CHARACTERIZATION (ELATERIDAE, AGRYPNINAE, HEMIRHIPINI)
}

\author{
Sônia A. Casari ${ }^{1,2}$
}

\begin{abstract}
Larva of Hemirhipus Latreille, 1825 is herein described for the first time. Larvae of Chalcolepidius porcatus (Linnaeus, 1767), from Peru, and Hemirhipus apicalis Candèze, 1857, from Argentina, are described and of Alaus myops (Fabricius, 1801), from USA (Illinois and Maryland), and A. oculatus (Linnaeus, 1758), from USA (Illinois and Florida), are redescribed and illustrated. A comparison among the known larvae in each genus is presented. An historical review and the larval characterization of five genera and fourteen species of Hemirhipini genera are also included.
\end{abstract}

KEYWORDS. Alaus, Chalcolepidius, Elateridae, Hemirhipus, larvae.

\section{INTRODUCTION}

The Elateridae larvae are usually characterized by having head prognathous or slightly declined, distinct frontal sutures, antennae 3 -segmented, $2^{\text {nd }}$ segment bearing apically one or many sensory appendages, apical segment reduced, mandibles relatively stout and usually with penicillus, stemmata absent or one large on each side of head, labrum fused to the head capsule forming nasal, stipites connate or fused to the labium forming a maxillolabial complex, maxilla with 2 -segmented galea, lacinia variable, maxillary palps 4 -segmented, tarsungulus bearing 2 basal setae, spiracles biforous with distinct ecdysial scar and without closing mechanism and anal region ventrally oriented. They are usually heavily sclerotized and rigid, subcylindrical ("wireworms") or flattened (BоOth et al., 1990; BeCKer, 1991).

BECKER (l.c.) characterized the larvae of Pyrophorinae [=Agrypninae] as "somewhat depressed and not too heavily sclerotized, have the ninth abdominal segment bifurcate (sometimes the first instar lacks the bifurcation), and have the pleural areas membranous and visible". Treating of the tribes, he did not consider Agrypnini, Pyrophorini and Hemirhipini separately, and stated "the larvae of Pyrophorini (Lacon, Alaus,

1. Museu de Zoologia da Universidade de São Paulo, Caixa Postal 42594, 04299-970, São Paulo, SP, Brasil. (casari@usp.br)

2. Bolsista CNPq. 
Chalcolepidius, Hemirhipus, Pyrophorus, Conoderus, Aeolus, etc.) have the submentum triangular, the mandible without teeth on the inner surface, and the tenth abdominal segment armed with teeth". Besides these characters, the larvae of Agrypninae are characterized especially by coloration yellowish with black head, dorsoventrally flattened body, one stemma on each side of head, well developed ventral epicranial ridge, lacinia lobed and setose. The larvae of Hemirhipini are characterized by having a dorsal epicranial ridge semicircular, from frontal arms to near base, coarsely and irregularly punctate and setose internally. This is the only character separating the Hemirhipini from Pyrophorini larvae, besides the presence of bioluminescence in the latter.

The tribe Hemirhipini is formed by 21 genera (CASARI-ChEN, 1994; CASARI, 1996b); larvae of only five genera and fourteen species are known: Alaus Eschscholtz, 1829 [A. myops (Fabricius, 1801), A. nobilis Sallé, 1855, A. oculatus (Linnaeus, 1758)], Calais Castelnau, 1836 [C. berus (Candèze, 1865), C. putridus (Candèze, 1857), C. speciosus (Linnaeus, 1767)], Chalcolepidius Eschscholtz, 1829 [C. approximatus Erichson, 1841, C. corpulentus Candèze, 1874, C. erythroloma Candèze, 1857, C. viridipilis (Say, 1825) and C. zonatus Eschscholtz, 1829], Paracalais Neboiss, 1967 [P. prosectus (Candèze, 1857)] and Pherhimius Fleutiaux, 1942 [P. dejeani (Candèze, 1857), P. fascicularis (Fabricius, 1787)]. The larvae of Hemirhipus Latreille, 1825 (H. apicalis Candèze, 1857) and Chalcolepidius porcatus (Linnaeus, 1767) are herein described by first time.

The material studied belongs to Field Museum of Natural History, Chicago (FMNH), Instituto Miguel Lillo, Tucumán (IMLA) and Smithsonian Institution, Washington (USNM).

\section{Alaus Eschscholtz, 1829}

The genus Alaus is formed by 11 species (CASARI, 1996a) distributed throughout of North, Central and South America. Larvae of Alaus myops, A. nobilis and A. oculatus are known.

The larvae of $A$. oculatus was briefly described by HARRIS (1841) and later described in details, including an illustration of dorsal habitus, by CHAPUIS \& CANDĖze (1853). JEWETT (1946) redescribed it illustrating the head (dorsal) and apex of abdomen (lateral, dorsal). Peterson (1960) presented the redescription with illustrations of habitus (dorsal), head (dorsal) and apex of abdomen (lateral). BECKER (1991) made a brief redescription and included, besides the Peterson's figures, also those of head and prothorax (ventral).

The larva of $A$. nobilis was described by SALLÉ (1855) that illustrated the dorsal habitus and head, also presented a comparison with $A$. oculatus. The larva of $A$. myops was described by ScHIODTE (1870), including the illustrations of habitus (dorsal), head (dorsal) and apex of abdomen (lateral).

\section{Alaus myops (Fabricius, 1801)}

(Figs. 1-15)

Redescription. Length: $42 \mathrm{~mm}$, width of pronotum: $6 \mathrm{~mm}$. Body dorsoventrally flattened. Yellow with head black and prothorax dark reddish-brown, meso-, mesonotum and legs reddish-brown; legs darker.

Head (figs. 1-3) prognathous, depressed; dorsal epicranial ridge irregular, semicircular, from frontal arms to near base, very coarsely and irregularly punctate and 

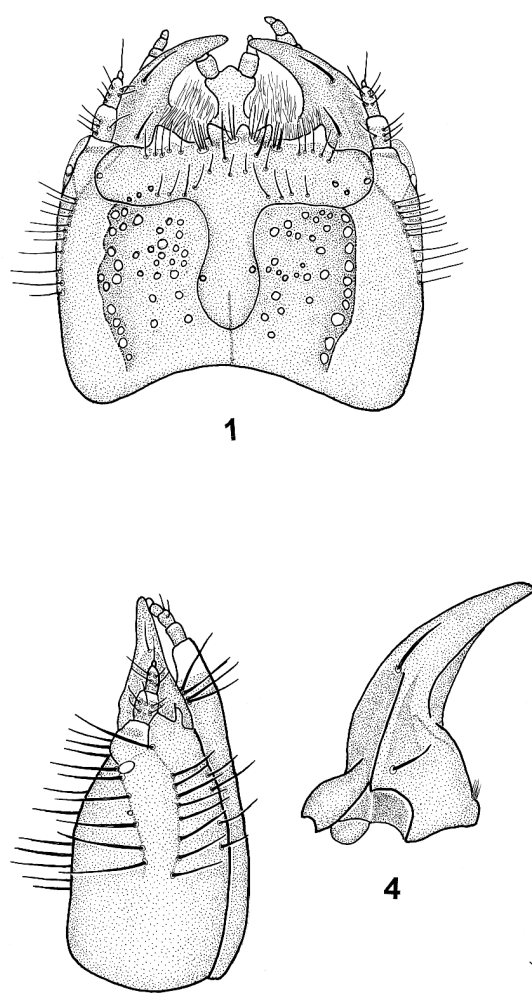

3

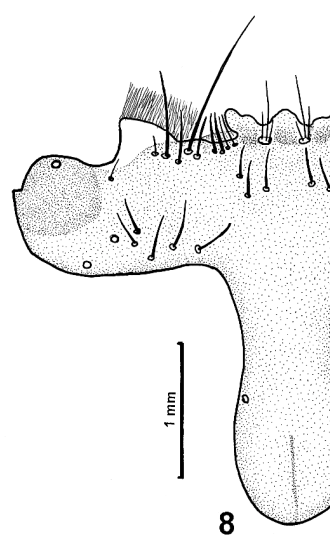

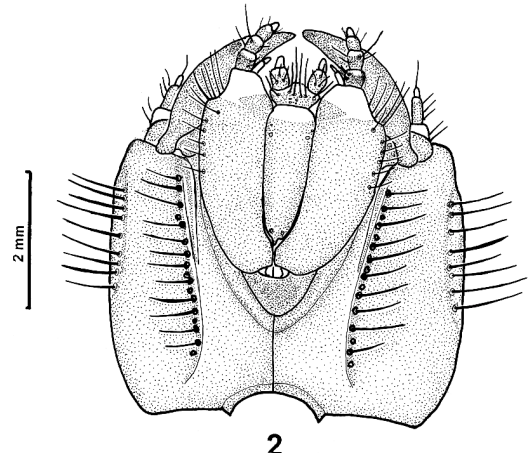

2
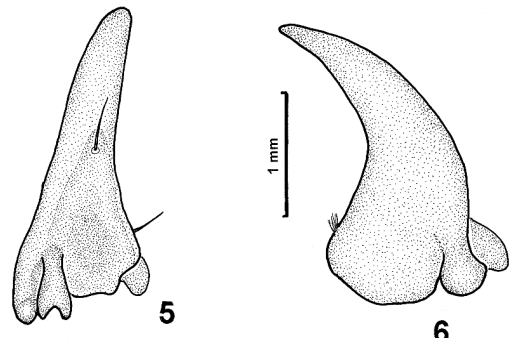

6

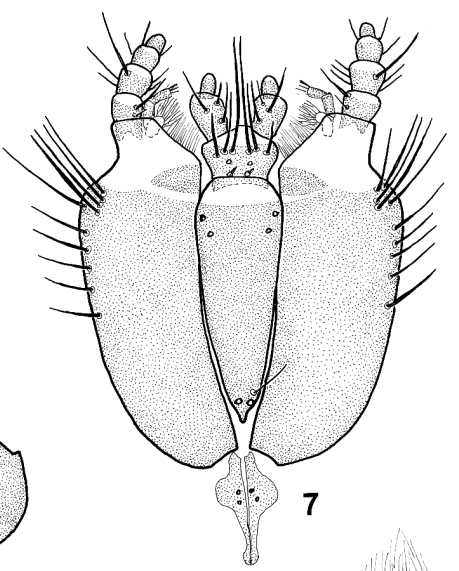

Figs. 1-9. Alaus myops (F.): 1-3, head, dorsal, ventral, lateral; 4-6, mandible, dorsal, lateral, ventral; 7, maxillolabial complex, ventral; 8, frons and nasal, dorsal; 9, nasal, ventral. Figs. 1-3; 4-7, to same scale. 
setose internally (setae not represented); ventral epicranial ridge almost straight, not reaching margins, with row of coarse setose punctures externally; each epicranial plate dorsally with one lateral inclined row of setae, starting in front of stemma and outside directed, and other ventrally parallel lateral margin. One subelliptical stemma (fig. 3) dorsolaterally placed at base of each antenna. Coronal suture (figs. 1, 8) long; dorsally weak groove extending between frontal arms. Endocarina absent. Frontal suture lyreshaped. Nasal (fig. 8) tridentate dorsally, teeth upwardly directed; three setae on each side of central tooth; ventrally (fig. 9) integument rugose, clothed with short setae, and with transverse anterior carina. Paranasal lobes (fig. 8) clear distally, marginate by ramified yellowish setae; 4 setae on each side of nasal; one row with 5 setae (one longer) near border of darker area, one short seta more lateral; each half with 11 setae (3 grouped below nasal) and one on each side, near middle of narrower area. Antennae (figs. 10, 11): basal segment bearing 12 setae (one fallen); $2^{\text {nd }}$ segment bearing 13 setae (one basal short); apex of $2^{\text {nd }}$ segment with tiny laterointernal cupuliform appendix; distal segment short and cylindrical, distally with one long and 2 short setae and 2 dorsal sensorial pores near base. Mandibles (figs. 4-6) very raised dorsally near acetabulum, deeply grooved laterally on median half; 2 dorsal setae; penicillus short and brushlike. Maxillolabial complex (figs. 7, 12): stipites elongate, membranous in narrow irregular distal area, bearing ventrally 10 setae near anterior half of lateral margin (5 forming group) and dorsally, 12 setae on anterior fourth; galea (fig. 13) palpiform and 2-segmented; apex of distal segment widened, bearing one cupuliform membranous appendix with microsetae and 3 long setae (one very wide); lacinia lobe-like, membranous at apex, marginate by fringe of ramified setae; maxilary palp 4-segmented, basal segment bearing 2 setae, second with 8, third with 5 and distal with some dorsal setae peg-like in groove; cardines elongate, wider at second fourth, each bearing 2 tiny setae; prementum transverse, pentagonal, membranous on anterior half, bearing 3 ventral setae on each side, disposed in transverse row at border of darker area (internal longer), 2 microsetae near base and 2 sensorial pores near middle; dorsally with 4 pairs of sensorial pores and 2 pairs of short setae; postmentum elongate, narrowed on distal half with apex constricted, membranous distally, 2 setae (fallen) on each side near distal border of darker area and 3 (2 fallen) near base; labial palp 2segmented; basal segment bearing 9 setae and distal bearing some dorsal setae peg-like in groove near base.

Pronotum slightly shorter than meso- and metanotum together, bearing a transverse row of long setae, parallel anterior margin, interrupted at middle, and 2 long and 2 short setae on each side, near middle. Mesosternum with one lateroanterior pair of well developed biforous spiracle with one seta near internal borders. Leg: coxa narrow, transverse, bearing moderate stout setae on distal third and long simple setae near margin; trochanter trapezoidal with stout and short setae on basal half and simple and long setae near posterior margin, and one short seta near anterior margin; femur elongate with stout and short setae near posterior margin and 2 simple setae at anterior margin; tibia elongate with stout and short setae near lateral and posterior margins, 4 simple setae near middle and 3 (one longer) near anterior margin; tarsungulus bearing 2 basal setae.

Each side of abdominal segments I-VIII bearing a pair of laterodorsal anterior biforous spiracle smaller than thoracic. Segment IX (figs. 14, 15) strongly notched in narrow almost parallel apical area; apex bearing 2 setose well developed upwards tubercles 


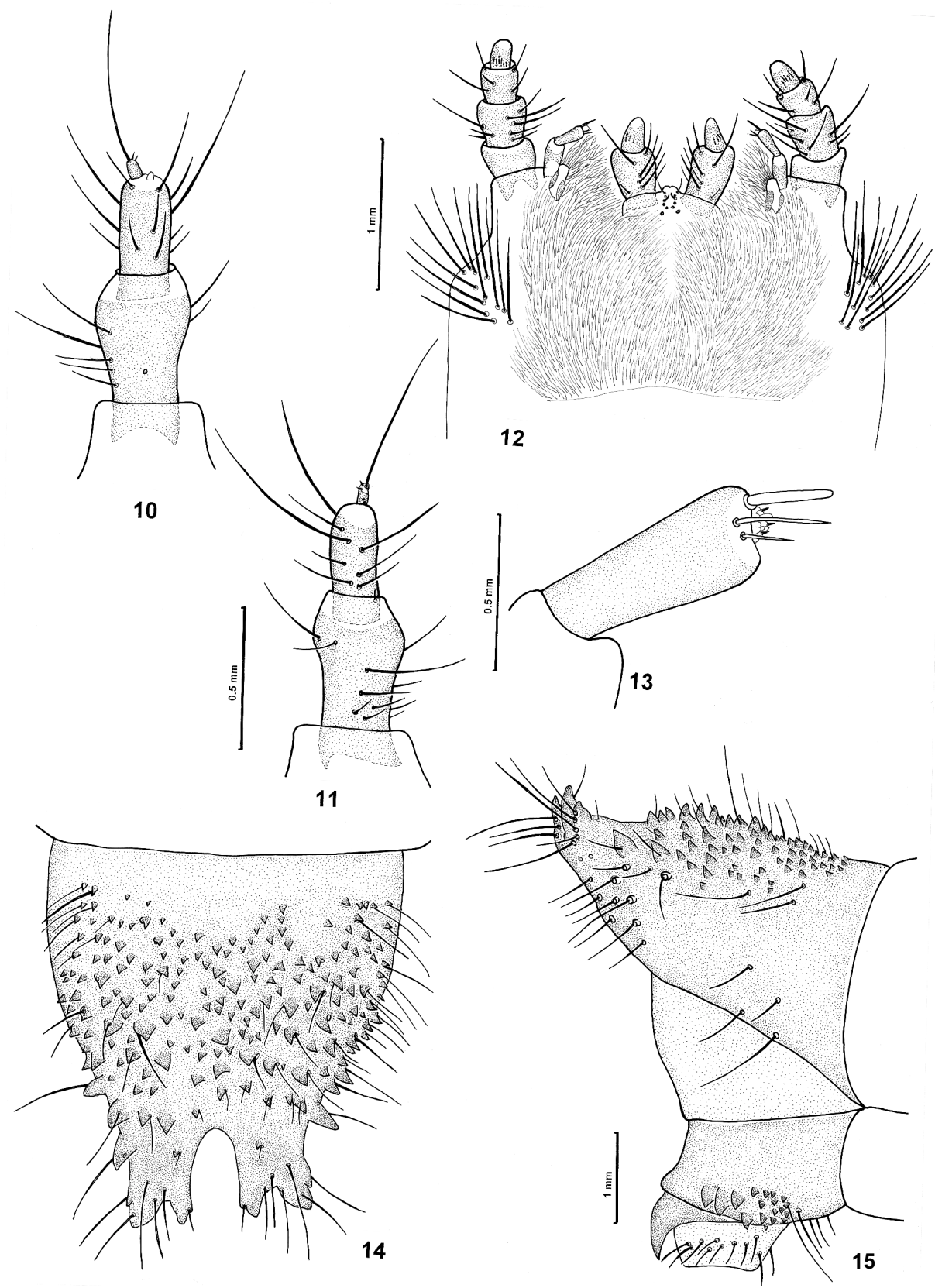

Figs. 10-15. Alaus myops (F.): 10, 11, right antenna, ventral, dorsal; 12, maxillolabial complex, dorsal; 13, galea, dorsal; 14, segment IX, dorsal; 15, segments IX-X, lateral. Figs. 10, 11; 14, 15, to same scale. 
on each side; dorsally with setose tubercles, irregularly disposed, decreasing in size basad; some marginal larger. Segment X (fig. 15) tubular, ventral, bearing 17 tubercles on each side (4 posterior larger) and 2 posterior distal hooks; anal opening surrounded by long setae.

Material examined. UNITED STATES OF AMERICA, Illinois: Willow Springs, 14.V.1922, William J. Gerhard (1 larva) (FMNH); Maryland: College Park, 06.IV.40, G. B. Vogt, ex-coll. Vogt (1 exuvia pinned with adult) (USNM).

\section{Alaus oculatus (Linnaeus, 1758)}

(Figs. 16-29)

Redescription. Length: $48-52 \mathrm{~mm}$, width of pronotum: 6-7 $\mathrm{mm}$ (larva illustrated = $49 ; 6 \mathrm{~mm}$ ). Yellow, almost orange with head black and prothorax, anterior region of mesonotum and legs dark reddish-brown.

Head (figs. 16, 17) prognathous, depressed; dorsal epicranial ridge irregular, semicircular, from frontal arms to near base, very coarsely and irregularly punctate and setose internally (setae not represented); ventral epicranial ridge almost straight, not reaching margins, with row of coarse setose punctures externally; each epicranial plate dorsally with one inclined row of setae, starting in front of each stemma and outside directed, and other ventrally parallel lateral margin. One subelliptical stemma dorsolaterally placed at base of each antenna. Coronal suture (figs. 16, 18) long; dorsally week groove extending between frontal arms. Endocarina absent. Frontal suture lyreshaped. Nasal (fig. 18) tridentate dorsally, teeth upwardly directed; 4 setae on each side of central tooth; ventrally (fig. 19) integument rugose, clothed with microsetae, and with transverse anterior carina and 2 setae near middle. Paranasal lobes clear distally, marginate by ramified yellowish setae; 4 long setae on each side nasal; one row with 6 setae (one longer) near border of darker area, one short seta more lateral; each half with 11 setae ( 3 in an inclined row below nasal) and one pair laterally near middle of narrower area. Antennae (figs. 25, 26): basal segment bearing 9 setae; $2^{\text {nd }}$ segment bearing 18 setae ( 7 fallen); apex of $2^{\text {nd }}$ segment with laterointernal cupuliform appendix; distal segment short and cylindrical, distally with one long seta. Mandibles (figs. 20-22) very raised dorsally near acetabulum, deeply grooved laterally on median half; 2 dorsal setae; penicillus short and brush-like. Maxillolabial complex (figs. 27, 28): stipites elongate, membranous in narrow distal area, bearing ventrally 10 setae near anterior half of lateral margin (4 forming group) and dorsally 22 setae on anterior fourth; galea (fig. 29) palpiform and 2-segmented; distal segment bearing, at apex, a cupuliform appendix with microsetae and 3 setae (wider broken); lacinia lobe-like, marginated by fringe of ramified setae; maxilary palp 4-segmented, basal segment bearing 2 setae, second 11, third 4 and distal with some dorsal setae peg-like in groove; cardines elongate, wider at second fourth, each bearing 3 tiny setae; prementum transverse, pentagonal, membranous on anterior half, bearing 3 ventral setae on each side (one fallen), disposed in transverse row at border of darker area (internal longer), 2 microsetae near base and 2 sensorial pores near middle; dorsally with 3 pairs of short setae, 3 pairs of microsetae and 3 pairs of sensorial pores; postmentum elongate, gradually narrowed posteriad, membranous distally, 2 setae on each side near proximal border of darker area and 4 near base (2 longer); labial palp 2-segmented; basal segment bearing dorsally 9 setae 

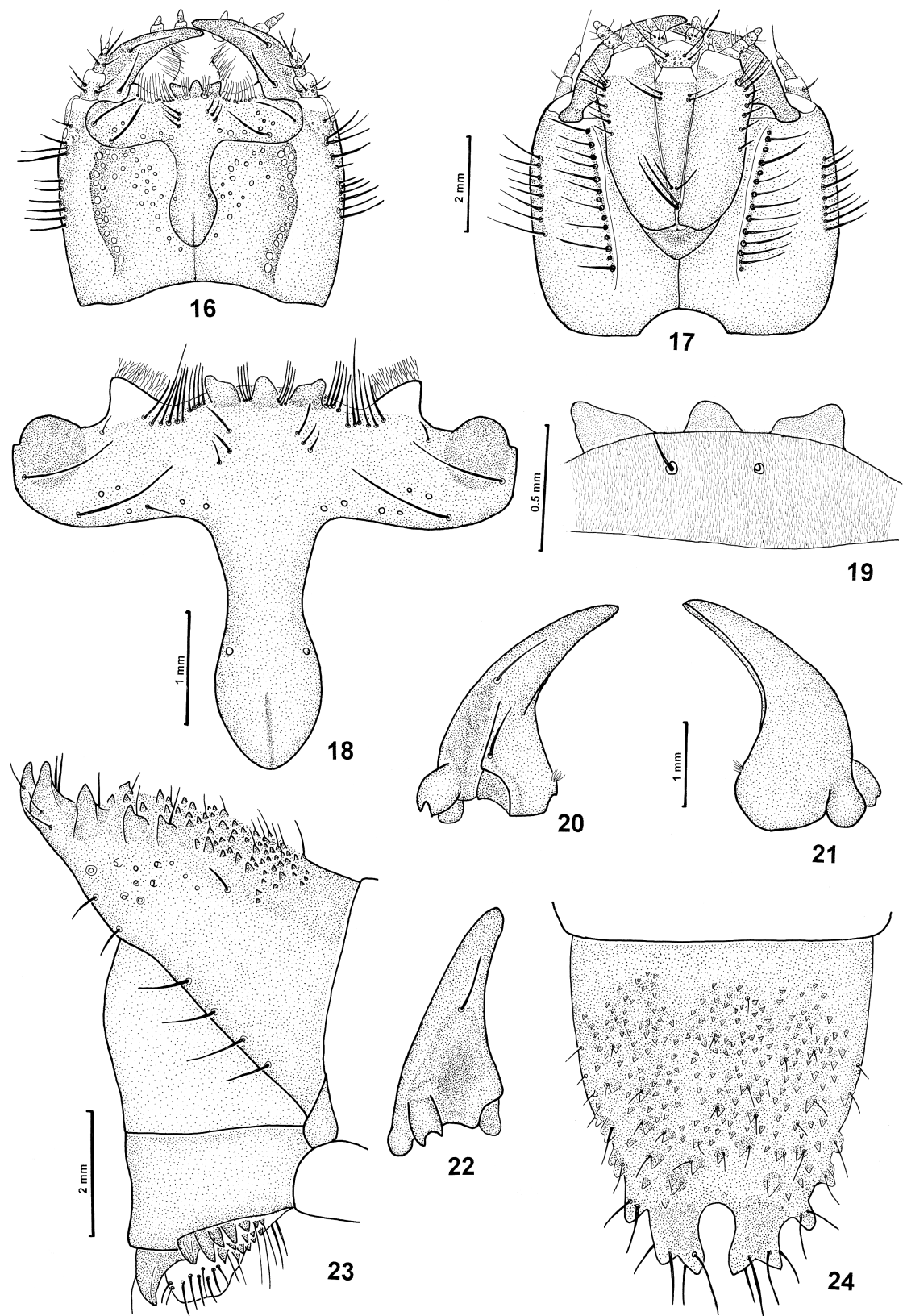

19

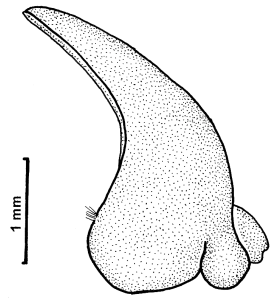

21

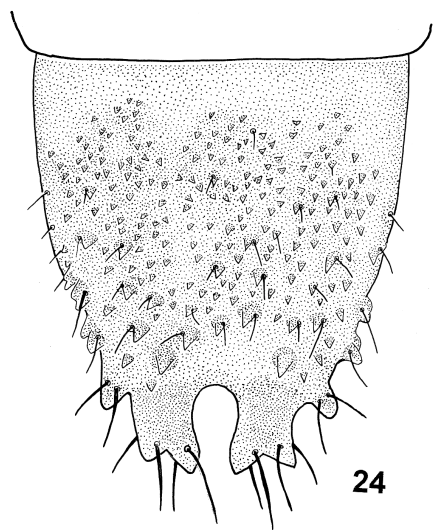

Figs. 16-24. Alaus oculatus (L.): 16, 17, head, dorsal, ventral; 18, frons and nasal, dorsal; 19, frons, ventral; 20-22, mandible, dorsal, ventral, lateral; 23, segments IX-X, lateral; 24 segment IX, dorsal. Figs. 16, 17; 20$22 ; 23,24$, to same scale. 
(5 grouped) and 8 sensorial pores, and 3 setae ventrally; distal segment bearing some dorsal setae peg-like in groove near base.

Segment IX (figs. 23, 24) strongly notched at apex; slit wider and rounded at base; apex bearing 2 setose upwards well developed tubercles on each side; dorsally with setose tubercles, irregularly disposed, decreasing in size basad; some marginal larger. Segment $\mathrm{X}$ (fig. 23), tubular, ventral, bearing on each side, 16 tubercles (4 larger) and 2 posterior hooks; anal opening surrounded by long setae.

Material examined. UNITED STATES OF AMERICA, Illinois: Glen Ellyn, VI.18.05, Alaus oculatus, A. B. Wolcott (1 larva dissected); Palos Park, V.30.07, E. B. Chafre (1 larva); Florida: Puncta Gorda, V.1941, H. Ramstadt (1 larva) (FMNH).

Comparing the known larvae of $A$. myops, A. nobilis and $A$. oculatus, it was observed: distal segment of galea with rounded apex and postmentum gradually narrow apicad in $A$. nobilis and $A$. oculatus, and apex of galea widened and postmentum narrowed on distal half and apically constricted in A. myops. Comparing A. myops with $A$. oculatus it was verified the following differences (later parenthesized): base of frons rounded (slighly narrowed), lateral seta of frons near anterior margin (near middle), nasal ventrally clothed with short setae (clothed with microsetae, bearing 2 moderately long setae), cardines bearing 2 tiny setae (3), setae of basal segment of labial palp not forming group (forming group) and slit at apex of segment IX almost straight (wider and rounded at base).

\section{Chalcolepidius Eschscholtz, 1829}

The genus Chalcolepidius is formed by 63 species distributed by North, Central and South America. Larvae of only five species were described: C. approximatus Erichson, 1841, C. corpulentus Candèze, 1874, C. erythroloma Candèze, 1857, C. viridipilis (Say, 1825) and C. zonatus Eschscholtz, 1829.

Dugés (1885) described the larva of $C$. zonatus, later recognized as $C$. approximatus. He presented detailed descriptions and illustrations of larva and pupa collected in Tupátaro (Mexico). BRUCH (1938-1942) treated the immatures and adult of $C$. corpulentus as $C$. limbatus. He presented the description of larva, pupa and adult, the drawings of larval antenna, frons and nasal, apices of labium and maxila, mandible and leg, and also photos of larva (dorsal and ventral habitus) and adult (dorsal habitus), apex of abdomen (dorsal, ventral, lateral) and head (dorsal, ventral). The larva of C. erythroloma was firstly described by SCHiodte (1870) who presented also a diagnosis for Chalcolepidius larva and illustrated the habitus (dorsal), head (ventral), leg, apex of abdomen (lateral) and spiracle; it was redescribed by XAMBEAU (1912). The larva of $C$. viridipilis was partially illustrated by BövING \& CRAIGHEAD (1931), who presented the drawings of maxillolabial complex, frons and nasal, mandible, head (lateral) and apex of abdomen (dorsal, lateral). The larva and pupa of C. zonatus was firstly described by Costa (1971), based on exuviae. She presented the drawings of maxillolabial complex, frons and nasal, mandible, antenna, leg and apex of abdomen (dorsal and ventral). CosTA et al. (1988) redescribed and illustrated the larva and pupa, based on fixed specimens. 


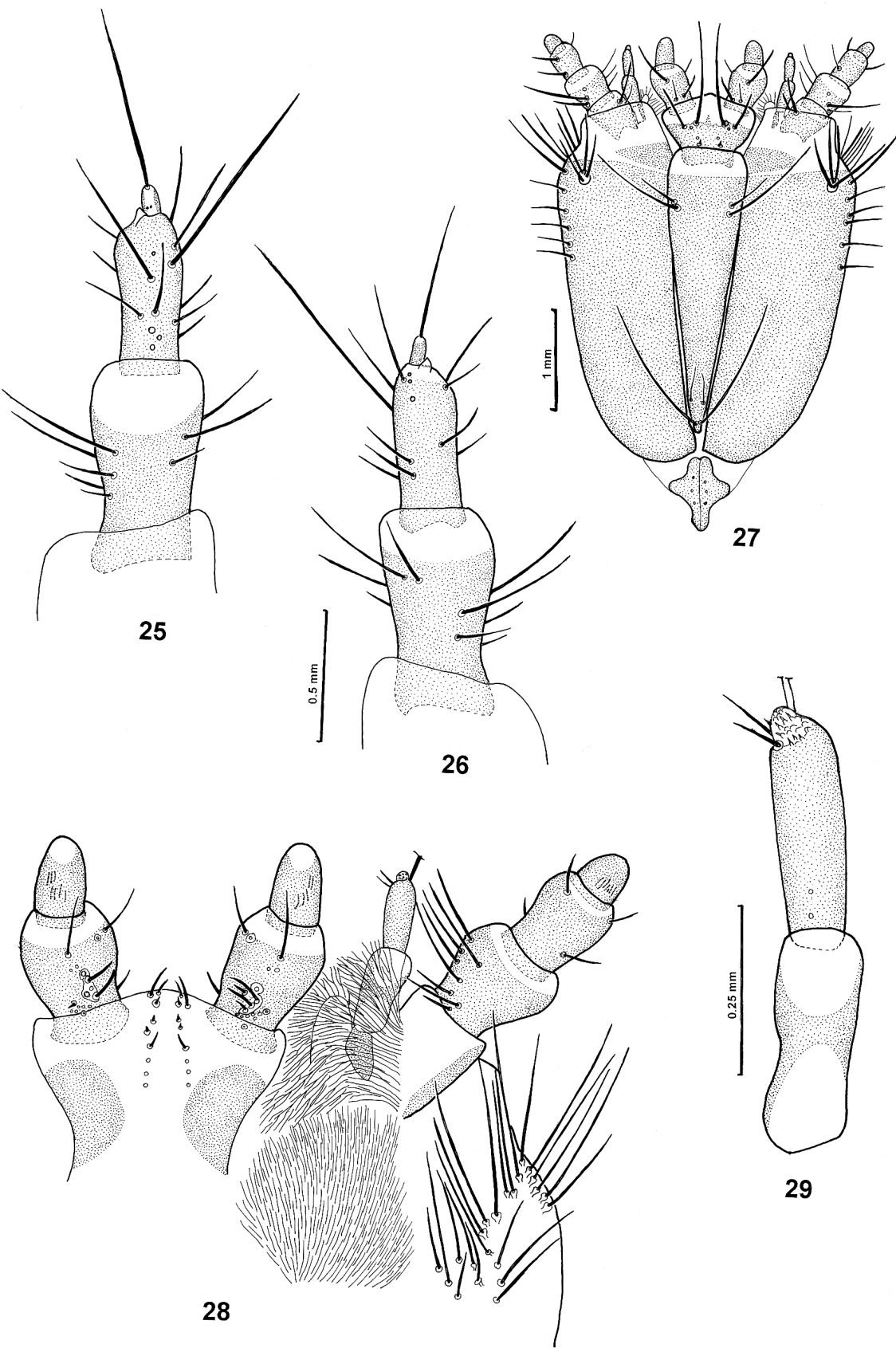

Figs. 25-29. Alaus oculatus (L.): 25, 26, right antenna, dorsal, ventral; 27, maxillolabial complex, ventral; 28, apex of maxillolabial complex, dorsal; 29, galea, dorsal. Figs. 25, 26, 28, to same scale. 


\section{Chalcolepidius porcatus (Linnaeus, 1767)}

(Figs. 30-50)

Description. Length: $34-58 \mathrm{~mm}$, width of pronotum: 4-8 $\mathrm{mm}$ (larva illustrated $=$ $51 ; 8 \mathrm{~mm}$ ). Yellow, almost orange with head black and prothorax, anterior region of mesonotum and legs dark reddish-brown (figs. 30, 31).

Head (figs. 32-34) prognathous, depressed; dorsal epicranial ridge semicircular, from frontal arms to near base, moderately coarse and irregularly punctate and setose internally; ventral epicranial ridge almost straight, not reaching margins, with row of coarse setose punctures externally; epicranial plates with one longitudinal row of setae dorsally, from below stemma until basal third, and other ventrally parallel lateral margin. One subelliptical stemma (fig. 33) dorsolaterally placed at base of each antenna. Coronal suture (figs. 32, 41) long; dorsally weak groove extending between frontal arms. Endocarina absent. Frontal suture lyre-shaped. Nasal (fig. 41) tridentate dorsally, teeth forwardly directed, lateral teeth wider; 2 setae each side of central tooth; ventrally (fig. 42) integument rugose and clothed with microsetae, with transverse anterior carina and 2 short setae near middle. Paranasal lobes clear distally, marginate by ramified yellowish setae; 4 long setae on each side of nasal; an irregular row 4 long setae near border of darker area, one short near anterior margin and one lateral; each half of frons with 8 setae and one pair laterally near middle of narrower area. Antennae (figs. 35-37): basal segment bearing 13 setae ( 2 fallen); $2^{\text {nd }}$ segment bearing 14 setae (one fallen); apex of $2^{\text {nd }}$ segment with one tiny laterointernal cupuliform appendix; distal segment short and cylindrical, distally with one long seta (fallen) and one group with 5 sensorial pores and one short pedunculate setae; 3 short setae near border of distal membranous area (2 fallen) and 2 dorsal sensorial pores near base. Mandibles (figs. 46-48) very raised dorsally near acetabulum, deeply grooved laterally on median half; 2 dorsal setae; penicillus short and brush-like. Maxillolabial complex (figs. 43, 45): stipites elongate, membranous in narrow irregular distal area, bearing 10 ventral setae near anterior half of lateral margin ( 3 forming group) and 16 dorsal setae on anterior fourth; galea palpiform (fig. 44) and 2-segmented; basal segment subtriangular bearing one seta and 2 sensorial pores; distal segment longer with rounded sensorial appendix and 3 setae at apex (one longer); lacinia lobe-like, densely setose covered dorsally by ramified and simple setae; maxilary palp 4-segmented, second segment bearing 9 setae, third with 6 and distal with one dorsal seta among some setae peg-like in groove near middle; cardines elongate, wider at second fourth, each bearing 2 tiny setae, densely microsetose at base; prementum transverse, narrowed at basal half, membranous on anterior half; bearing 3 ventral setae on each side (internal longer), at border of darker area, disposed in transverse row, 2 short setae near base and several sensorial pores; dorsally with 4 sensorial pores at middle, 2 crossed setae with one microseta on each side, near anterior margin, 3 paired microsetae below crossed setae and 3 small setae ( 2 fallen) on each side, near base; postmentum elongate, subtriangular, membranous distally, one short and one long seta on each side near distal border of darker area and 2 near base; labial palp 2-segmented; basal segment bearing 7 setae and distal bearing some dorsal setae peg-like in groove near middle.

Pronotum (fig. 30) as long as meso- and metanotum together laterally and longer at median line, bearing one tranverse lateroanterior band of setae, interrupted at middle, near anterior and posterior margins (anterior longer). Prosternum (fig. 31) bearing 2 


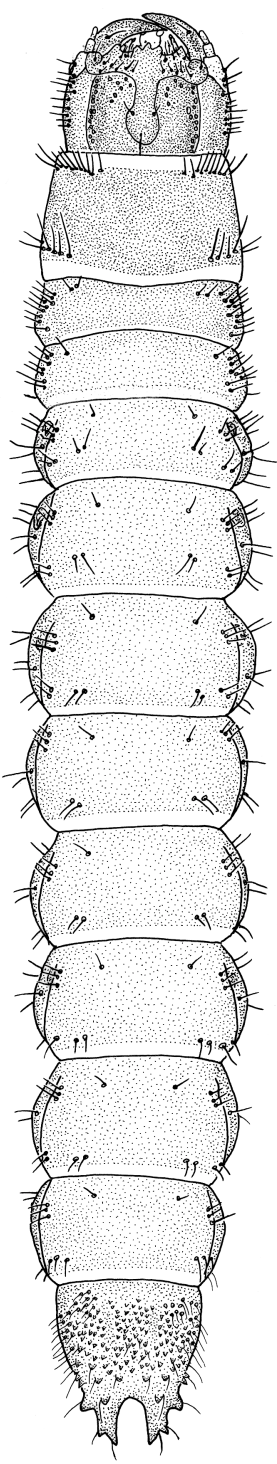

30
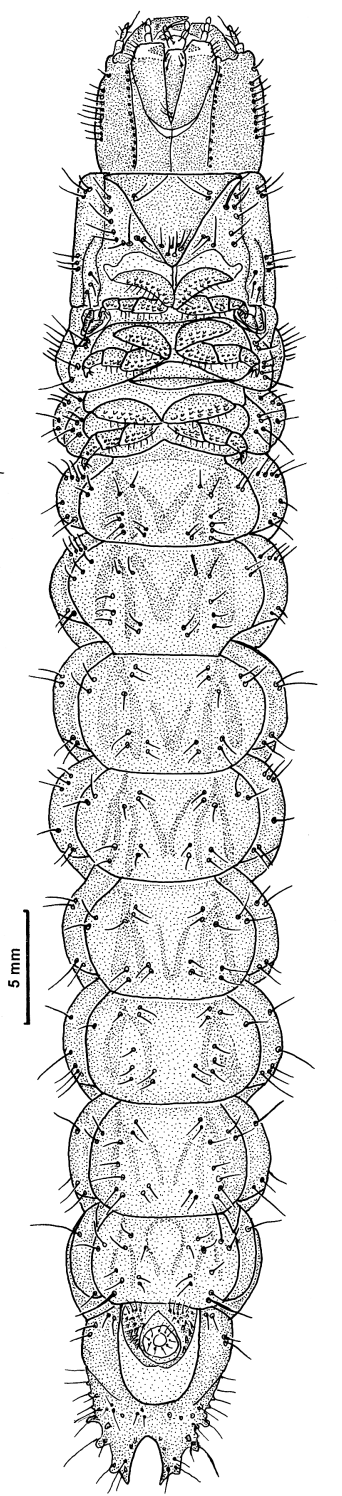

31
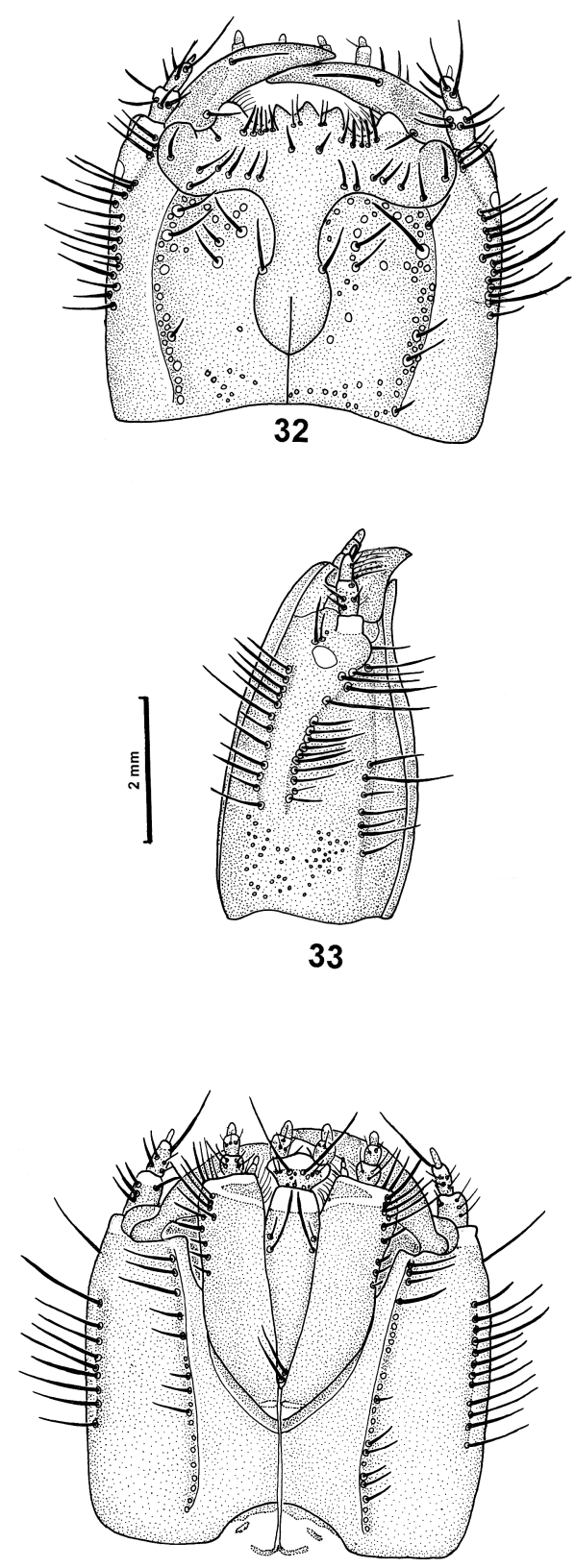

34

Figs. 30-34. Chalcolepidius porcatus (L.): 30, 31, habitus, dorsal, ventral; 32-34, head, dorsal, lateral, ventral. Figs. 30, 31; 32-34, to same scale. 

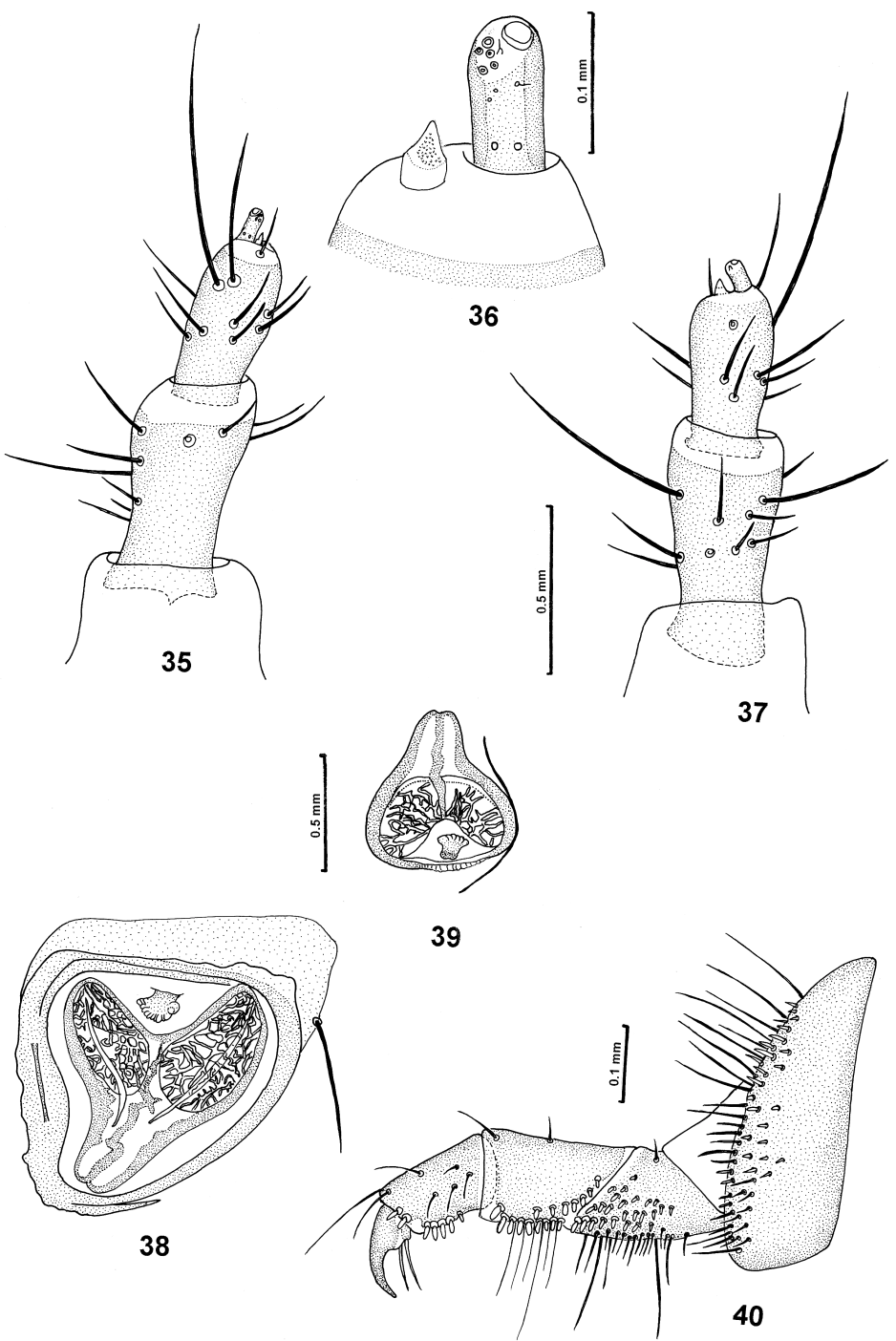

Figs. 35-40. Chalcolepidius porcatus (L.): 35-37, antenna, ventral, apex ventral, dorsal; 38, 39, spiracles, thoracic, abdominal; 40, right mesothoracic leg, external. Figs. 35, 37; 38, 39, to same scale.

setae near each fore angle and a group at base. Each side of mesonotum with 11-12 setae and metanotum with 8 setae. Mesosternum with one lateroanterior pair of well developed biforous spiracle (fig. 38) with one seta near internal borders. Leg (fig. 40): coxa narrow, transverse, bearing moderate stout setae on distal third and long simple setae near margin; trochanter trapezoidal with stout and short setae on basal half and simple and long setae near posterior margin, and one short seta near anterior margin; 

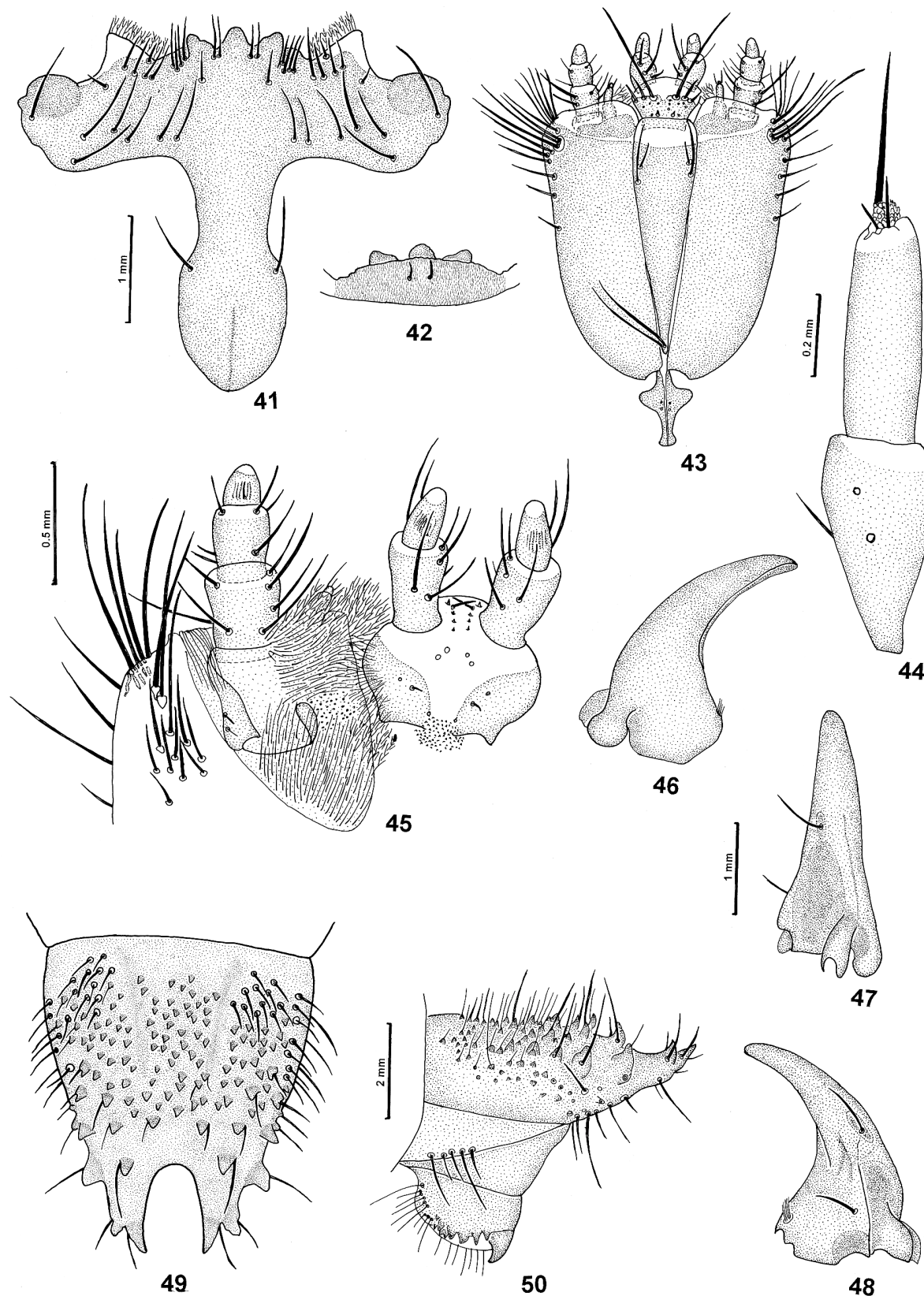

43
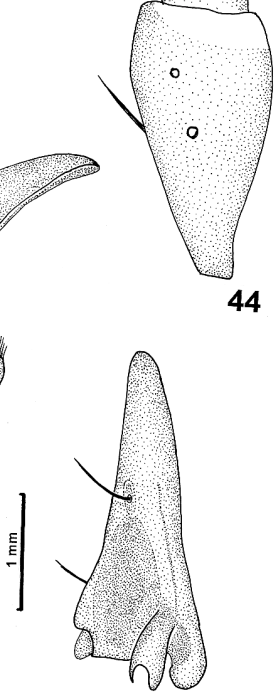

47

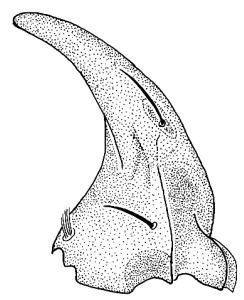

48

Figs. 41-50. Chalcolepidius porcatus (L.): 41, frons and nasal, dorsal; 42, nasal, ventral; 43, maxillolabial complex, ventral; 44, galea, dorsal; 45, apex of maxillolabial complex, dorsal; 46-48, mandible, ventral, lateral, dorsal; 49, segment IX, dorsal; 50, segments IX-X, lateral. Figs. 41, 42; 43, 46-48; 49, 50, to same scale. 
femur elongate with stout and short and long simple setae near posterior margin and 2 simple setae at anterior margin; tibiae elongate with stout and short setae near lateral and stout and short and long simple setae near posterior margins, 4 simple setae near middle and 3 (one longer) near anterior margin; tarsungulus bearing 2 basal setae.

Each side of abdominal segments I-VIII (figs. 30, 31) bearing 6 dorsal, 5 dorsolateral on each side, 4 lateral and 24-26 ventral setae; one pair of laterodorsal anterior biforous spiracle (fig. 39) smaller than thoracic. Segment IX (figs. 49, 50) widely notched at apex, bearing setose tubercles dorsally and laterally; each side of apex with 2 very developed upwards tubercles; internal margins of slit convergent at apex; 2 transverse subapical rows, one with 2 and other with 3 pairs of tubercles; remainders irregularly disposed and decreasing in size basad; ventrally, small tubercles laterally and setose sclerotized plates near apex and at median basal area. Segment X (fig. 50) tubular, ventral, bearing 6 setose tubercles on each side, disposed near margin and 2 posterior distal hooks; anal opening surrounded by long setae.

Material examined. PERU, Loreto: Estirón, Rio Ampiácu, Dec. 5, 1961, B. Malkin leg., 5 larvae associated to one female (FMNH).

Comparing the larva of $C$. porcatus with the described larvae of other species, it was not found significant differences among them. A comparison of the chaetotaxy was not possible because, usually, the setae were not described and partially represented. Comparing C. porcatus with the described material of C. zonatus, it was observed only small differences on chaetotaxy.

\section{Hemirhipus Latreille, 1825}

The genus Hemirhipus is formed by 9 species (CASARI, 1998) distributed throughout Mexico, Central and South America.

The present description is based on illustrations taken, some years ago, from one exuvia of Hemirhipus apicalis from Instituto Miguel Lillo (S.[antiago] del Estero, La Verole, 30.X.48, F. Luna col.).

\section{Hemirhipus apicalis Candèze, 1857}

(Figs. 51-57)

Description. Dorsally bearing asperites (fig. 53) from mesonotum to ninth tergite. Head (figs. 51, 52) black, strongly and coarsely punctate; dorsal epicranial ridge semicircular and near lateral margin; nasal forming one rounded lobe; paranasal lobes well developed and bilobed; frons with a transverse carina on each side, small punctate internally, and one seta on each side near base; base of frons strongly narrowed; ventral epicranial ridge almost straight, not reaching base. Coronal suture (fig. 51) very long; dorsally weak groove extending between frontal arms on basal third of frons. Mandibles very robust. Maxillolabial complex (fig. 52): stipites narrow, elongate and convergent basally; maxilar palpi 4-segmented; left maxillar palp double; cardines separated from stipites; postmentum shorter than stipites, with rounded apex; labial palpi 2-segmented. Antennae 3-segmented. All segments of legs (fig. 54) with stout setae. Spiracles biforous. Segment IX (figs. 55-57) with tubercles on distal half, decreasing in size basad; apex with 2 larger tubercles followed by 2 smaller near 


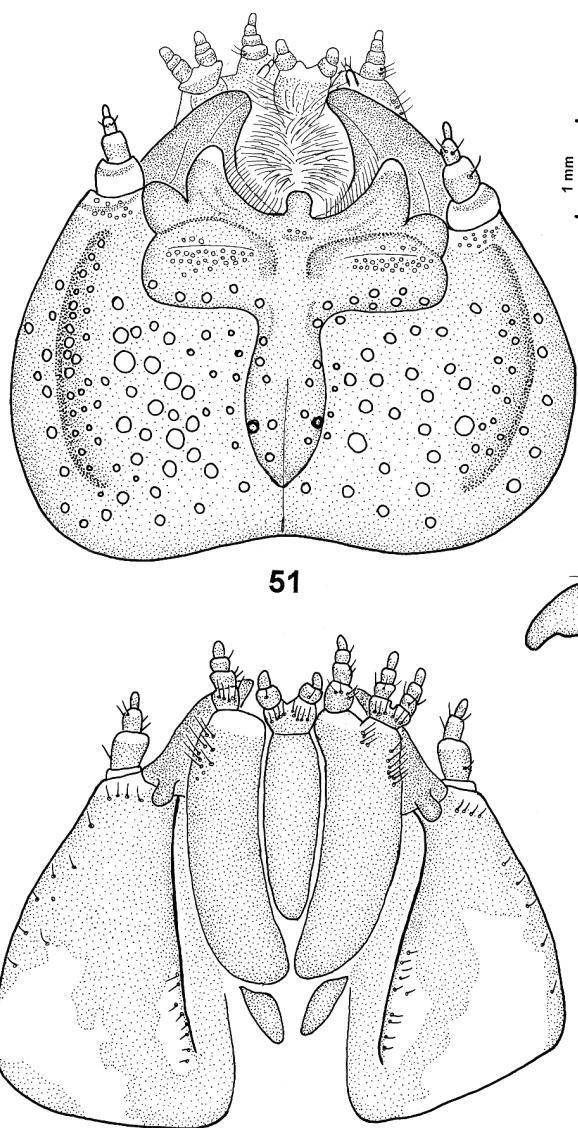

52
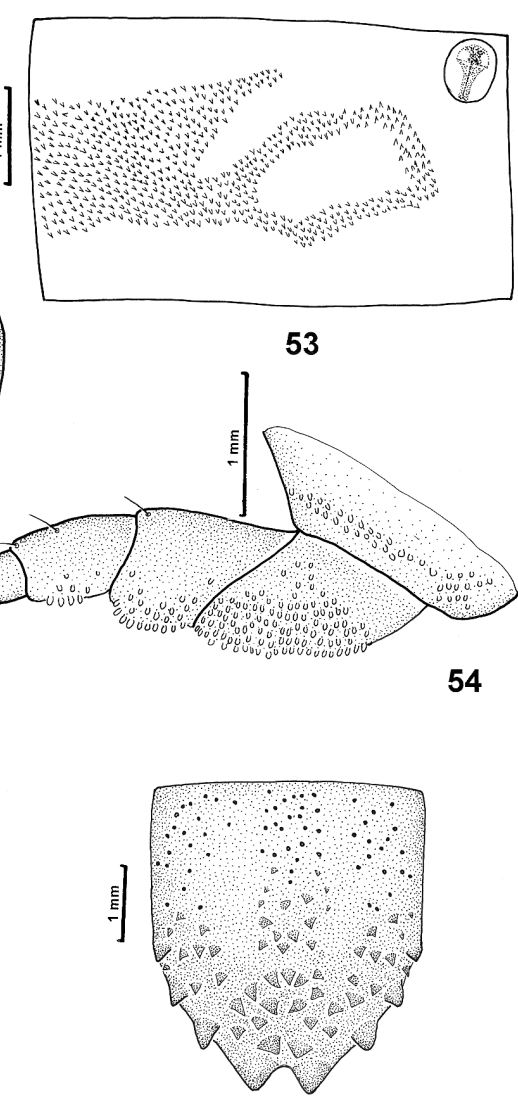

55
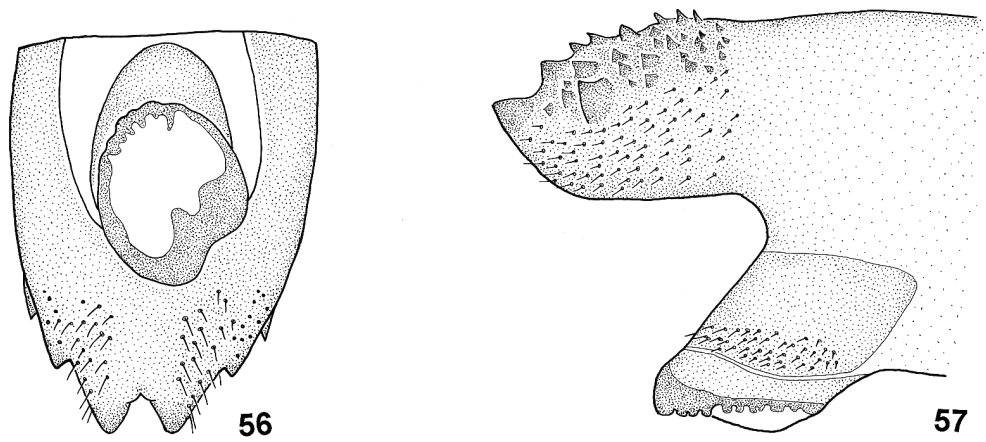

Figs. 51-57. Hemirhipus apicalis Candèze: 51, 52, head, dorsal, ventral; 53, right half of $1^{\text {st }}$ tergite; 54, leg; 55 , segment IX, dorsal; 56, 57, segments IX-X, ventral, lateral. Figs. 51, 52, 55, 57 to same scale. 
middle; three lateral (including distal) larger each side and several smaller irregularly distributed, more concentrate near middle of distal half. Segment X (figs. 56, 57) marginate distally by sclerotized toothed plate, and one row of setae internally. The majority of setae were fallen and could not been represented.

\section{Pherhimius Fleutiaux, 1942}

The genus Pherhimius is formed by two species (CASARI, 1996b) distributed throughout of North, Central and South America. The larvae of two species are known. The larva of P. fascicularis was firstly illustrated by Böving \& CRAIGHEAD (1931) and described by Peterson (1960). CASARI \& BeLlusci (1996) described the larva and pupa of Pherhimius dejeani (Candèze, 1857) and redescribed the larva of P. fascicularis (Fabricius, 1787). The larvae of Pherhimius, like that of Hemirhipus, present dorsal asperites, mandibles very robust, postmentum very shorter than stipites and ninth tergite slightly notched at apex, bearing dorsally few tubercles.

\section{Calais Castelnau, 1836}

The genus Calais includes 183 species (CASARI-CHEN, 1994) from Afrotropical, Palearctic, Oriental and Australian regions. Larvae of three species are known: C. speciosus as described by CANDĖze (1861) and C. berus and C. putridus, by KAWADA et al. (1959) and OHIRA (1962).

CANDĖze (1861) studied one Elateridae larva from Ceylon that he supposed to be Calais speciosus: “... a la plus grande analogie avec les larves d'Alaus et peut-étre celle de l'A. speciosus". He did not describe it; only presented one drawing of habitus (dorsal) and other of segment IX. Based on his illustration, it is possible to observe that the mandibles are extremely slender, the frons is narrow and elongate and the segment IX very concave dorsally, with apex bifurcate. These characteres are not related with Agrypninae larvae and this species does not belong to Hemirhipini.

KAWADA et al. (1959) described, the larvae of Alaus berus and Alaus putridus, illustrating the dorsal habitus and the segment IX (dorsal) of both species. OHIRA (1962) redescribed the larva of Calais berus and illustrated the dorsal habitus, head (dorsal and ventral), mandible (dorsal and ventral), antenna, prothorax (ventral), spiracle, apex of maxillolabial labial complex (dorsal), segments IX-X (lateral) and leg. Based on KAWADA et al. (1959) illustrations, the larvae of Calais present the Hemirhipini characters and, the segment IX is strongly notched at apex with slit U-shaped in C. berus and V-shaped in C. putridus pini; both species present 2 distal tubercles on each side of apex of segment IX and 2 tubercles on each side of base of slit, and the remainders, irregularly distributed, decreasing in size basad. By illustrations of OHIRA (1962), more numerous and detailed, it is verified that the larva of Calais is very similar to those of Alaus and Chalcolepidius.

\section{Paracalais Neboiss, 1967}

The genus Paracalais is formed by 21 Australian species, with larva of only one species known. The larva and pupa of $P$. prosectus (Candèze, 1857) were described and illustrated by CASARI \& COSTA (1998). The larva of P. prosectus is very similar to those of 


\section{Alaus, Calais and Chalcolepidius.}

Remarks. Comparing the known larvae of Hemirhipini, it is verified that those of Alaus, Calais, Chalcolepidius and Paracalais are very similar, especially by general coloration, presence of slender mandibles and shapes of the body and segment IX.

Larvae of Alaus are characterized especially by presence of dorsal epicranial ridge semicircular, irregular, strong and coarsely punctate innerly; each half of frons with 11 setae; frons with 3 setae on each side below nasal; nasal tridentate with teeth upwardly directed; postmentum constricted bearing 2 or 4 setae near base; dorsal tubercles of segment IX, irregularly disposed, except 2 distal on each side; apical slit of segment IX straight or widened and rounded at base.

Larvae of Chalcolepidius are characterized by dorsal epicranial ridge semicircular, regular and moderately coarse punctate; nasal tridentate with teeth forwardly directed; each half of frons with 8 setae; frons with one seta on each side below nasal; postmentum gradually narrowed basad and with 2 setae near base; subapical tubercles on segment IX disposed in 2 transverse rows with 2 and 6 tubercles, and remainders irregularly distributed, decreasing in size basad .

Larvae of Calais are characterized by dorsal epicranial ridge straight (?); frons with one seta on each side below nasal; postmentum gradually narrowed apicad with base wide and rounded, bearing 2 basal setae; subapical dorsal tubercles of segment IX disposed in one row of 4 tubercles, and remainders irregularly distributed, decreasing in size basad.

Larvae of Paracalais are characterized by frons with 2 setae on each side below nasal; distal segment of antennae bearing 2 long setae; postmentum gradually narrow basad; segment IX strongly notched at apex, forming a V-shaped slit; subapical dorsal tubercles of segment IX disposed in one row of 2 tubercles and remainders irregularly disposed, decreasing in size basad.

The larvae of Hemirhipus and Pherhimius are also very similar, especially by presence of dorsal asperites and mandibles very stout and segment IX slightly notched at apex. The larva of Hemirhipus is characterized by presence of asperites from mesonotum to ninth tergite; head very strongly punctate; dorsal epicranial ridge semicircular, very near lateral margin; nasal forming one rounded lobe; paranasal lobes bilobed; frons with a transverse carina on each side; mandibles very robust; cardines separated from stipes; postmentum shorter than stipites, with base rounded; without slit at apex of segment IX; segment X marginate distally by sclerotized plate toothed distally.

The larvae of Pherhimius are characterized by asperites from mesonotum to ninth tergite; nasal formed by one triple tooth; mandibles robust; frons bilobed laterally to paranasal lobes; cardines fused to stipites and bearing one moderately long seta; postmentum shorter than stipites, slightly narrowed and rounded at base; ninth tergite bearing dorsally few tubercles, decreasing in size basad with 2 larger at apex followed by 2 transverse rows with 4 and 7 tubercles; remainder tubercles smaller and irregularly disposed; apex of segment IX slightly notched and upwards.

Acknowledgements. To David G. Furth and Nathalia J. Vandenberg (USNM), A. F. Newton Jr. (FMNH) and R. Golbach (IMLA) (in memorian) for loan of the material studied, and also to Ricardo Pinto da Rocha (Instituto de Biociências, USP) and Carlos Roberto F. Brandão (Museu de Zoologia, USP) for suggestions on tittle and illustrations. 


\section{REFERENCES}

BeCKer, E. 1991. Elateridae (Elateroidea). In: SteHr, F. W. ed. Immature insects. Dubuque, Kendall/Hunt Publ. v. 2, p. 410-417.

Воотн, R. G.; Cox, M. L. \& MADGE, R. B. 1990. IIe guides to insects of importance to man. 3. Coleoptera. Cambridge, UK, International Institute of Entomology, The Natural History Museum. 384p.

Böving, A. G. \& CRaighead, F. C. 1931. Illustrated synopsis of the principal larval forms of the order Coleoptera. Entomol. am., New York, 11:1-352.

Bruch, C. 1938-1942. Misceláneas entomológicas. Notas Museo La Plata, La Plata, 7(57):141-151.

CANDĖze, M. E. 1861. Histoire des métamorphoses de quelques Coléoptères exotiques. Mém. Soc. Roy. Sci. Liége, Liège, 1861:1-86, 6 pl.

CASARI, S. A. 1996a. Systematics and phylogenetic analysis of Alaus Eschscholtz, 1829 (Coleoptera, Elateridae). Revta bras. Ent., São Paulo, 40(2):249-298.

1996b. Revision of Pherhimius Fleutiaux, 1942 with establishment of the Saltamartinus, new genus (Coleoptera, Elateridae, Pyrophorinae, Hemirhipini). Papéis Avuls Zool., São Paulo, 39 (21):379-403.

- 1998. Revision of Hemirhipus Latreille, 1825 (Coleoptera, Elateridae). Revta bras. Ent., São Paulo, 41(24):317-334.

CASARI, S. A. \& Bellusci, S. 1996. Larvae of Neotropical Coleoptera XXV.Pherhimius dejeani (Candèze, 1857) and P. fascicularis (Fabricius, 1787) (Elateridae, Pyrophorinae, Hemirhipini). Iheringia, Sér. Zool., Porto Alegre, (80):55-63.

CASARI, S. A. \& COSTA, C. 1998. Description of larva and pupa of Paracalais prosectus (Candèze) (Elateridae, Agrypninae, Hemirhipini). Revta bras. Zool., Curitiba, 15(3):703-708.

CASARI-CHEN, S. A. 1994. Systematics and evolution of Hemirhipini from Old World and Australia. II. Phylogeny of the tribe including the American genera (Coleoptera, Elateridae, Pyrophorinae). Revta bras. Ent., São Paulo, 38(1):161-252.

Chapuis, M. F. \& CANDÈze, M. E. 1853. Catalogue des larves des Coléoptères, connues jusqu'a ce jour avec la description de plusieurs espèces nouvelles. Mém. Soc. roy. Sci. Liège, Liège, 8:341-653.

Costa, C. 1971. Descrição de fases imaturas de Pyrophorinae neotropicais (Coleoptera, Elateridae). Revta bras. Ent., São Paulo, 15(4):21-30.

Costa, C.; Vanin, S. A. \& CASARI, S. A. 1988. Larvas de Coleoptera do Brasil. São Paulo, Museu de Zoologia, Universidade de São Paulo. 282p.

Dugés, D. E. 1885. Métamorphoses du Chalcolepidius zonatus Eschs. Ann. Soc. ent. Belg., Bruxelles, 29(2):3239.

HARRIS, T. W. 1841. A report on the insects of Massachusetts injurious to vegetation. Cambridge, Folsom, Wells \& Thurston. 459p.

Jewett, H. H. 1946. Identification of some larval Elateridae found in Kentucky. Ky. Agr. Exp. Sta. Bul., Lexington, 489:1-40.

KAWADA, A. et al. 1959. Illustrated insect larvae of Japan. Tokyo, Hokuryukan [iv]1-8, 1-712, [ii]1-73, 150 .

OHIRA, H. 1962. Morphological and taxonomic study on the larvae of Elateridae in Japan (Coleoptera). Okazaki, Univ. Okazaki. 179 p.

Peterson, A. 1960. Larvae of Insects. An introduction to Nearctic species. Part II. Coleoptera, Diptera, Neuroptera, Siphonaptera, Mecoptera, Trichoptera. Columbus, A. Peterson. 416p.

SAllé, M. A. 1855. Description de dix espèces nouvelles de Coléoptères, recueillis de 1849 a 1851 dans la République Dominicaine (ancienne partie espagnole de L'ile de Saint-Domingue ou Haïti). Annls Soc. ent. Fr., Paris, 3(3):263-272.

Schiodte, J. C. 1869-1870. De metamorphosi eleutheratorum observationes: bidrag til insekternes udviklingshistoire. Naturh. Tidssk., Copenhagen, 6(3):467-530.

Xambeau, C. 1912. Moeurs et metamorphoses des insectes. $18^{\mathrm{e}}$ memoire. Elaterides. Première partie. Soc. Linn., Bordeaux, 59(1):12-161. 